Covered in: ERIH PLUS, CEEOL, Index Copernicus, CrossRef, CrossCheck, J-Gate, Google Scholar, Ideas RePeC, Econpapers, Socionet, KVK, WorldCat.

\section{Fasting, a Means to Spiritual, Bodily and Social Health}

\section{Traian-Alexandru MIU1}

${ }^{1}$ Assistant, Ph.D., Valahia University, Targoviste, Romania, E-mail: traianalexandrumiu@gmail.com
Abstract: In Eastern spirituality fasting has both a physical and a spiritual side. Physical fast involves refraining oneself from consuming certain types of food and reducing the amount of food allowed to be consumed. The spiritual fast implies the spiritualization of the human being by avoiding hollow thoughts, facts that are against moral laws, inappropriate words. Both physical and spiritual fast create the proper conditions that lead to spiritual and bodily health. The purpose of fasting is the spiritual ascension, the bodily health being only a side effect of the ascetic endeavors of the human being. A person can only be declared healthy if both his/her soul and his body are in good health. Of course, the medical aspects of fasting should not be forgotten either, the Christian having the duty of properly taking care of his body, by not neglecting or disregarding it. Having a dichotomous nature, the human being must be concerned with the soul, but also with the body, fasting being the means by which the soul manages to dominate the passionate impulses of the body.

Fasting has an important religious-moral value, it is a welcome act to God, a means of removing passions and sins, an instrument of lust control, a separation from the materialism of the present world. Fasting is a way to acquire the moral order within society, being a means of Christian philanthropy, an instrument of helping people, a way through which society can progress.

Keywords: fasting; moderation; health; consumerism; sins.

How to cite: Miu, T.A. (2019). Fasting, a Means to Spiritual, Bodily and Social Health. Logos Universality Mentality Education Novelty: Philosophy \& Humanistic Sciences, 7(2), 62-72. doi: 10.18662/lumenphs/27 


\section{Introduction}

Aspects regarding fasting are one of the main preoccupations of the contemporary Orthodox theology, this also being ascertained by the Holy and Great Synod of Crete (June 16 - 26, 2016), where an official document regarding fasting was adopted, document which will be referred to later in the present paper. In the Eastern spirituality fasting has a great moral importance, being a means by which we can work on personal perfection, with consequences on the physical level, but also on the social level. Of course, fasting is an act whereby man honors God and a way to get rid of passions, to acquire virtues. The Holy Fathers deepened, both practically and theoretically, all the values of fasting, giving us testimony of its benefits, recommending it for strengthening the spiritual life as fasting is a means of following Christ. Orthodox theology, when dealing with fasting, speaks of two sides of it: the spiritual and its physical one. The spiritual fasting takes into consideration the spiritualization of man by avoiding empty thoughts, facts that are against moral laws, and inappropriate words. Physical fasting involves restraining from consuming certain types of food and reducing the amount of food allowed to be consumed. Both spiritual and physical fasting creates the conditions conducive to spiritual and bodily health.

\section{Scriptural and patristic grounds for fasting}

Fasting, with its two sides, that of 'humility' and that of 'abstaining from something' (Cornițescu, 1991: 90) has sound arguments in the Holy Scripture and the Holy Tradition.

The Holy Fathers considered that the first form of fasting has a heavenly origin, being recommended by God to the first people so that they may come to completion by obeying Him, that is, to go through the path that makes them attain likeness to the Creator (Acts 2, 16-17). Saint Basil the Great gives us a testimony in this regard, stating: 'The law of fasting was given in heaven. Adam was first given the command to fast: "Do not eat from the tree of the knowledge of good and evil." The words "Do not eat" represent a law of fasting and restraint. If Eve had fasted and had not eaten from the tree, she would not have needed the fast, because "the healthy ones do not need doctors, but the sick ones do". (...) We did not fast, and we were banished from heaven! Let us fast in order to return to heaven!' (Saint Basil the Great, 2009: 48-49). If man had obeyed God's commandment of not eating the fruit of the tree of knowledge, he would have not died. By not obeying, man reached the death of his soul and body. We can deduce from 
here that the fasting that God had ordained had the capacity to strengthen both man's soul, by advancing to deification, and man's body, giving him the possibility of not knowing damage and physical death.

The practice of fasting is presented to us by numerous texts in the Old Testament. Some of the most significant one are presented below:

- Deuteronomy 9, 18: „And I fell down before the LORD, as at the first, forty days and forty nights: I did neither eat bread, nor drink water, because of all your sins which ye sinned, in doing wickedly in the sight of the LORD, to provoke him to anger.";

- Isaiah 58, 6-7': „Is not this the fast that I have chosen? to loose the bands of wickedness, to undo the heavy burdens, and to let the oppressed go free, and that ye break every yoke? Is it not to deal thy bread to the hungry, and that thou bring the poor that are cast out to thy house? when thou seest the naked, that thou cover him; and that thou hide not thyself from thine own flesh?" assembly!"

- Joel 2, 15: „Blow the trumpet in Zion, sanctify a fast, call a solemn

- Jonah 3, 5: „So the people of Nineveh believed God, and proclaimed a fast, and put on sackcloth, from the greatest of them even to the least of them."

At the same time, the books of the New Testament state the existence of the fasting institution:

- Jesus Christ Himself before beginning His public ministry fasted for forty days: „And Jesus being full of the Holy Ghost returned from Jordan, and was led by the Spirit into the wilderness, being forty days tempted of the devil. And in those days he did eat nothing: and when they were ended, he afterward hungered." (Luke 4, 1-2).

- The Savior advises on how fasting should be: „Moreover when ye fast, be not, as the hypocrites, of a sad countenance: for they disfigure their faces, that they may appear unto men to fast. Verily I say unto you, They have their reward. But thou, when thou fastest, anoint thine head, and wash thy face; That thou appear not unto men to fast, but unto thy Father which is in secret: and thy Father, which seeth in secret, shall reward thee openly." (Matthew 6, 16-18).

\footnotetext{
${ }^{1}$ It should be mentioned that almost completely chapter 58 of Isaiah refers to fasting, the way it was observed by the Jewish people, and the way God calls it to be observed, the chapter having the subtitle 'The True Fasting'.
} 
- Acts 13, 2: „As they ministered to the Lord, and fasted, the Holy Ghost said, Separate me Barnabas and Saul for the work whereunto I have called them."

- Acts 14, 23: „And when they had ordained them elders in every church, and had prayed with fasting, they commended them to the Lord, on whom they believed."

- Romans 14, 20-21: „For meat destroy not the work of God. All things indeed are pure; but it is evil for that man who eateth with offence. It is good neither to eat flesh, nor to drink wine, nor any thing whereby thy brother stumbleth, or is offended, or is made weak."

These scriptural testimonies prove to us that fasting is a means by which we can acquire the virtue of the temperance, we can repent of our sins and ascend to spirituality. Fasting is a path of humility and restraint of the body, a means of spiritual enhancement and closeness to the holy things.

The Holy Fathers have given special importance to fasting, because it can restore us to the state of spiritual and bodily cleansing that we once lost during the paradise period, it can restore us to the foundations of a gracious life in order to increase the communion state in love. Some examples of the multitude of teachings that the Holy Fathers left on fasting are given below:

- Saint Basil the Great: 'Fasting gives birth to prophets and strengthens the powerful. Fasting makes lawgivers wise. Fasting is a good safeguard for the soul, a steadfast companion for the body, a weapon for the valiant, and a gymnasium for athletes. Fasting repels temptations, anoints unto piety; it is the comrade to watchfulness and the artificer of chastity' (St. Basil the Great, n.d.).

- Saint John Chrysostom: 'Do you fast? Then feed the hungry, give drink to the thirsty, visit the sick, do not forget the imprisoned, have pity on the tortured, comfort those who grieve and those who weep. Be merciful, humble, kind, calm, patient, sympathetic, forgiving, reverent, truthful and pious so that God might accept your fasting and might plentifully grant you the fruits of repentance. (Fr. Dcn. Matthew Steenberg, n.d.).

- Saint John of Damascus: '(...) It is good to fast every day, but the one who does not eat should not judge the one who eats. In these cases, there should be no laws, no constraints; it is not proper to rule the flock of God; rather, use advice, gentleness, and wise words' (Saint John of Damascus, n.d.).

- Saint Seraphim of Sarov: 'Fasting consists not just of eating rarely, but also of eating little. And not just in eating only one meal, but in not 
eating much. Foolish is the faster, who waits for a specific time [to eat a meal], but then at the time of the meal is completely consumed, body and mind, with insatiable eating' (***. (n.d.). Teachings of St. Seraphim of Sarov on Fasting).

- Saint John of Kronstadt: 'It is necessary for a Christian to fast, in order to clear his mind, to rouse and develop his feelings, and to stimulate his will to useful activity. These three human capabilities we darken and stifle above all by "surfeiting, and drunkenness, and cares of this life'(St. John of Kronstadt, n.d.).

The Fathers of the Church practiced fasting themselves and they left us teachings, based on what they learned from doing so. The personal example has the highest value in education, this being applied when it comes to the purpose of fasting, its benefits for the whole community of people. Fasting had the role of raising them to a high level of bodily and soul experience. That is why, by obeying the Savior's advice, the teachings of the Holy Scripture and of the Fathers of the Church, we impart the wonderful fruits of fasting.

\section{The spiritual value of fasting}

As mentioned above, according to the Holy Bible, the notion of fasting initially had the sense of obedience and humility of man towards God, this being the natural manifestation honoring the Creator and our faith in Him. In Hebrew, the term 'ana (h)' is used to highlight the meaning of obedience and humility of fasting. The term is also encountered in the first beatitude of Jesus Christ in the Sermon on the Mount, when he says that 'the humble/obedient' ${ }^{2}$ to God will inherit the kingdom of heaven (Corniţescu, 1991: 87). The Hebrew expression of "soul humbling" emphasizes the value of fasting from the spiritual point of view, which means that it is closely linked to the heavenly origin of the fast, stated by the Holy Fathers. In heaven, fasting meant first people's obedience to God, as they fed themselves with "herb bearing seed, which is upon the face of all the earth, and every tree, in the which is the fruit of a tree yielding seed" (Genesis 1, 29).

They had a vegetarian lifestyle, specific to fasting, but disobedience to God, that is, the sin of pride, opposed to humility, made them lose the

\footnotetext{
2 In the Romanian translations of the Holy Bible, the term 'ana (h)' was translated by the word 'poor' (the Hebrew word 'ony', which derives from the verb 'ana (h), meaning 'poor'), but this translation has restricted the meaning of fasting only to material abstinence (Cornițescu, 1991: 87).
} 
right to remain in heaven, afterwards carrying in their soul the nostalgia of the lost paradise. The vegetarian diet was beneficial to their body; that is why until the flood of Noah, the descendants of Adam and Eve enjoyed great longevity. After the flood, God, for the preparation and strengthening of the human race, will allow the consumption of flesh (Acts 9: 3), which they will abuse and thus lose their longevity' (Cornițescu, 1991:87).

Fasting is obedience, humility, restraint, renunciation, goodness, the ability to rise from the material to the spiritual aspects of life. Fasting ennobles the soul; it has the capacity to clear the mind and to lift it to the holy things. Giving up the material possessions emphasizes our hunger and thirst for God, making both the body and the soul acquire special values such as: spiritual acuity, increased attention to the holy things, victory over sin, beauty and love.

By fasting we exercise our will and we manifest ourselves as free persons released from any constraint that could separate us from our purpose. Fasting gives us the ability to choose the good at the expense of evil. It makes us able to precisely distinguish between good and evil.

Fasting means change: changing the habits that make us slaves, detachment from all that brings routine, advancement towards the holy things, continuous evolution, endless progress in the spiritual life, and everlasting ascension in communion with God. 'The thirst for change is a universal law for all people' (Yannaras, 2000: 82). Fasting changes us, spiritualizes us, transfigures us, and breaks us from the everyday habits; it helps us to overcome the barriers of the fallen nature and to achieve that transparency which allows the holy light to manifest in its fullness. The luminous faces of the saints are the proof of the possibility of evolution, change, and transfiguration. The saint shows presence, dynamics, freedom, all these being gained through ascetic needs.

Fasting has an important religious-moral value, being a good deed to God, a means of removing passions and sins, an instrument of dominating lusts and of earning virtues.

\section{The bodily value of fasting}

Talking about the benefits of fasting for the health of the body, Saint John Chrysostom stated: "I am afraid of fasting because it damages and weakens the body", you may say. But you should know that the more corrupted the man's physical part becomes, the more his soul renews itself' (see 2 Cor. 4:16). On the other hand, if you want to research the topic in depth, you will find out that fasting takes care of the bodily health. And if 
you do not believe my words, ask the doctors to tell you better. They say that health is maintained by eating moderately, while greed leads to all kinds of diseases that destroy the body' (Saint John Chrysostom, n.d.)

The purpose fasting is the spiritual ascent, the bodily health being only a side effect of the ascetic endeavors of man. Bodily health can be maintained through a careful selection of the foods we consume, but also through their rationalization, that is, through temperance. Moreover, the virtue of temperance is the basis of the advancement to higher stages of fasting. Temperance is the virtue preached by the Holy Apostle Paul: „, Let us walk honestly, as in the day; not in rioting and drunkenness, not in chambering and wantonness, not in strife and envying. But put ye on the Lord Jesus Christ, and make not provision for the flesh, to [fulfil] the lusts [thereof. (Romans, 13, 13-14)

Man can only be declared healthy if both his soul and his body are in good health. Obviously, the medical aspects of fasting should not be neglected either, the Christian having the duty of properly taking care of his body, by not hurting or disregarding it. Being dichotomous, the human being must take care of the soul, but also of the body. Both physical and spiritual fasting creates the conditions conducive to spiritual and bodily health.

Physical fasting involves restraining from consuming certain types of food and reducing the amount of food allowed to be consumed. In doing so, we ensure our physical health, being responsible for the gift of life given to us by the Good God. The World Health Organization believes that 'dietary factors account for at least 30\% of all cancer cases in Western countries and up to $20 \%$ in developing countries. Leading researchers in England and Germany have shown that vegetarians in these countries are $40 \%$ less likely to develop cancer, compared to meat consumers, and The American Cancer Research Institute, established, in 2007, through important studies regarding food, nutrition and cancer prevention, that for cases of cancer of the esophagus, lungs, pancreas, stomach, bowel, cervix and prostate, the consumption of red meat (beef, pork, lamb) and especially the consumption of processed meat has increased the risk of illness' (Diaconu, 2016: 150-151). The conclusion we are interested in would be that 'People who fast rarely get cancer' (Chirilă, Popescu, 2014:9).

From the above, we should not understand that the Church would condemn those who eat food of animal origin. The church promotes moderation, the natural order in the consumption of the material goods, the observance of the established fasting periods, all these leading to spiritual 
and bodily benefits. The fact that medical research confirms the need for a balanced diet is an additional proof of the human being's need to fast.

Based on the Orthodox fasting, a fasting diet, called 'Diet 5:2' or 'intermittent fasting' was created, which involves reducing the amount of food consumed in two non-consecutive days per week (for example: Wednesday and Friday). In these two days, women should not consume foods that exceed 500 calories per day, and men should not exceed 600 calories. All other days one can consume the normal number of calories the body needs (Ritta Madenn, 2018, pp. 103-104). In doing so, it has been shown that this diet 'helps many health issues, such as losing weight and reducing body fat levels; improving the level of sugar in the body and cholesterol; blood pressure reduction; increasing longevity; risk reduction of heart attack, heart disease and cancer' (Madenn, 2018: 105).

Of course, fasting is much more than a diet, its value being specified since the beginning of the present paper, but its positive results on physical health are also worth noting.

\section{The social value of fasting}

In the official document of the Holy and Great Council of Orthodox Church The importance of fasting and its observance today, we are told that '.. . as fasting without merciful deeds is dead, especially nowadays when the unequal and unjust distribution of goods deprives entire nations of their daily bread (Sfântul și Marele Sinod: Importanța postului și respectarea lui astări, 2016). Thus, fasting has the ability to help human society to eliminate social inequalities by properly referring to its neighbors, to their help, philanthropy being the side without which fasting loses its true purpose. Mercy involves personal sacrifice, communion with fellows, interpersonal collaboration to achieve the desideratum that Christianity preaches, that is, unity in Christ. 'That they all may be one; as thou, Father, art in me, and I in thee, that they also may be one in us: that the world may believe that thou hast sent me.' (John 17, 21).

Fasting has the capacity to make us escape from the materialism of the present world. It is a way to acquire the moral order within the society, being a means of Christian philanthropy, an instrument of self-help between people, and a means by which society can progress. Of course, temperance must be the virtue that comes to the support of the believer when fasting, helping him to maintain good moral and social conduct. Temperance must govern the person's daily life in relation to himself, but also to his fellows and the environment. Worldwide statistics show that the consumption of 
tangible goods per capita and, consequently, the quantities of waste have greatly increased. A study conducted in Romania, in 2013, by a waste recycling company, concluded that 'a Romanian from the urban area generates on average, during a year, approximately 346 kilograms of household waste (plastic, metal, paper-cardboard, glass, food scraps, etc.), while rural people produce, on average, about 95 kilograms of household waste/year' (Ziarul Lumina, 2013). A Eurostat report from 2017 shows that in the European Union the countries that generate the biggest amounts of household waste are: 'Denmark (the leading position), where a resident throws 777 kilograms of waste annually, followed by Cyprus (640 $\mathrm{kg} /$ inhabitant), Germany - $627 \mathrm{~kg}$ and Malta (621 kg/inhabitant)' (Neagu, 2018). From the official data presented above we can ascertain our greed for consuming material goods. We hear everywhere that we live in a 'consumer society', so things are well known, and even significant economic growth based on the increased consumption is reported. Ever since the 1950s, economist Victor Lebow (1955) has been encouraging the consumerist mentality, stating that it is the present economy that encourages people to consume more and more expensive things, seeking for spiritual satisfactions by means of consumption. The problems can be solved if we act individually, if we take into account the counsel of the Church to be moderate, if we also think about the person next to us and, why not, about the environment, all being gifts received from the Good God that we need to take care of. The consumerist mentality to which we feel that we are indebted should be defeated by the moderate consumption of goods. Statistics show that $99 \%$ of what we buy turns into garbage in six months. Let us first look at our homes and see how many useless things surround us.

\section{Conclusions}

Fasting has quite interesting meanings in the contemporary world: it can fight against consumerism and it is a way of solving the financial crises that distress humanity. Moderation in the consumption of material goods and mastery of passionate impulses of any kind are the ways to be followed for a peaceful and harmonious life.

Fasting involves repossessing the values for human life. In a world where non-values have become values, fasting has the purpose of restoring man to the path that leads to God, to anchor him in a good life based on prayer and the exercise of virtues. By fasting we refuse to consume with the soul and mind everything that is ephemeral, imaginary, or false, and we manage to aspire to the eternal good. Fasting is an exercise of the will, a 
manifestation of the spiritual and bodily powers with which God has endowed us, it is a state of enlightenment, joy, and active will. It is the triumph of eternity over the ephemerality, the victory of temperance over gluttony, the success of love over hatred. By fasting we show our impermanence and the spiritual poverty of human nature, but it is in this way that we discover the power of God who works precisely on our weaknesses. Fasting reveals to us who we are and what God is. Fasting heals the soul, the body, and, at the same time, cures the society of the disorder produced by sins.

\section{References}

***. (n.d.). Teachings of St. Seraphim of Sarov on Fasting. Retrieved from https://stjohndc.org/en/orthodoxy-foundation/lessons/teachings-stseraphim-sarov-fasting.

Ziarul Lumina (2013). Anual, un român generează 346 kg de deşeuri menajere [Yearly, a Romanian generates $346 \mathrm{~kg}$ of household waste]. $16 \mathrm{dec}$. 2013. Retrieved from https://ziarullumina.ro/societate/actualitate-sociala/anual-un-romangenereaza-346-kg-de-deseuri-menajere-87484.html.

Chirilă, P., Popescu, C. (2014). Prevenirea cancerului cu un studiu economic comparat [Cancer prevention with a comparative economic study]. Cluj-Napoca: Presa Universitară Clujeană.

Cornițescu, E. (1991). Sensul postului după Sfânta Scriptură. Biserica Ortodoxă Română, 4-6: 1991.

Diaconu, L. (2016). Hrana vieții fericite a monabilor. Fundamente biblice, patristice și canonice despre alimentația vegetariană și lacto-vegetariană [The food of the happy life of the monks. Biblical, patristic and canonical foundations on vegetarian and lacto-vegetarian nutrition]. Iasi: Doxologia.

Lebow, V. (1955). Price Competition in 1955. Journal of Retailing. Retrieved from https://www.gcafh.org/edlab/Lebow.pdf.

Madenn, R. (2018). Hrana, credinta și postul. O călătorie sacră spre o sănătate mai bună [Food, faith and fasting. A sacred journey to better health]. Iaşi: Doxologia.

Neagu, L. (2018). Eurostat: Românii genereaz̧ă cele mai puține deşeuri din Uniunea Europeană [Eurostat: Romanians generate the least waste in the European Union]. Retrieved from https://www.economica.net/eurostat-romanii-genereazacele-mai-putine-deseuri-din-uniunea-europeana 156774.html.

Saint Basil the Great (2009). Omilia I. Despre post, in Omilii și cuvantări, P.S.B I. Bucureşti: Basilica.

Saint John Chrysostom. (n.d.). Folosul postului [Use of the fasting]. Retrieved from https://www.ioanguradeaur.ro/723/folosul-postului/. 
Saint John of Damascus. (n.d.) Despre sfintele posturi, 3, PG 95, 68 B,

Sfântul și Marele Sinod: Importanța postului și respectarea lui astăzi (2016). [Holy and Great Synod: the importance of the position and its respect today] Retrieved from https://basilica.ro/sfantul-si-marele-sinod-importanta-postului-sirespectarea-lui-astazi-document-oficial/

St. Basil the Great. (n.d.). Homily I. Retrieved from https://www.crkvenikalendar.com/post/post-svetivasilije_en.php.

St. John of Kronstadt. (n.d.). My Life in Christ. Retrieved from http://www.orthodoxchurchquotes.com/2013/12/14/st-john-ofkronstadt-it-is-necessary-for-a-christian-to-fast-in-order-to-clear-his-mind/.

Steenberg, Fr. Dcn. Matthew. (n.d.). St. John Chrysostom on the Charity of Fasting. Retrieved from bttp://ww1.antiochian.org/st-john-chrysostom-charity-fasting.

Yannaras, C. (2000). Foamea şi setea [Hunger and thirst]. Bucureşti: Anastasia. 